\section{Clinton pledges more money for science next year}

[WASHINGTON] Science in the United States will enjoy healthy funding growth next year, following a decision by the Clinton administration to bow to pressure from scientific societies and their supporters in the Senate.

The administration has said it will ask for the money in its 1999 budget proposal, to be released on 2 February. Officials say the budget proposal will ask for increases of more than 7 per cent at the National Institutes of Health (NIH) and 9 per cent at the National Science Foundation. There will be smaller increases above inflation at other science funding agencies.

The increases are part of a $\$ 10$ billion investment package which the administration says is partially contingent on the ability ofCongress to pass complexlegislation to settle a major dispute between tobacco companies and state governments. But officials say that the package will be funded from other sources if the legislation fails, and science lobbyists are confident that money will be found for the increases in the event of such a failure.

Clinton's decision to boost science funding has come after a year of intensive lobbying by societies representing three million scientists and engineers, culminating in a December letter-writing campaign by members of the American Physical Society and the American Chemical Society.

Congress had expressed its own readiness to boost research spending. On 4 December, a letter from four key senators, including Pete Domenici (Republican, New Mexico), the chairman of the Senate Budget Committee, asked the administration to respond to their proposal to double research spending over ten years. The administration was able to make a positive response after budget projections released earlier this month enabled Clinton to announce that he would balance the entire budget in 1999 - three years earlier than anticipated.

The vanishing budget deficit puts Clinton in a good position to win approval for his investment plans. But the proposals for science spending are likely to have particularly strong support from both parties in the Congress. Lobbyists are optimistic that the increase for the NIH will be considerably larger than Clinton has proposed.

Last Saturday (10 January), Clinton devoted his weekly radio address to science and technology, pledging to support them in the budget and to expand on his plans for them in his State of the Union address at the end of this month. "Our nation was founded by men and women who firmly believed in the power of science to transform their world for the better," he said.

Colin Macilwain

\title{
Collapse of charity boosts call for tighter oversight
}

[LONDON] The government agency that registers Britain's charitable organizations has come under fire for licensing a medical

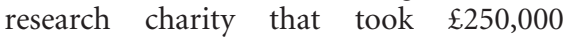
(US\$403,000) from the public and spent 80 per cent of this sum on "administrative costs" without contributing a penny towards research. The charity went into liquidation last year.

The Charity Commission is being criticized by the Association of Medical Research Charities (AMRC) for its handling of the Transplant Research Foundation, whose motto was: "Don't take your organs to Heaven - Heaven knows we need them here."

The foundation, which stated that its goal was to "support and carry out research into organ transplants and aftercare for the public benefit", went into liquidation following a year-long investigation by the commission. The investigation was prompted by complaints from researchers about delays in processing their grant applications, as well as about the use of "unconventional" methods for assessing project proposals.

The investigation revealed that the foundation lacked a standard procedure, and access to trained scientific personnel, for assessing research applications. The foundation had received 90 applications for grants worth $£ 90,000$, but no funds were given out.

The case has important implications for the licensing of medical research charities. Diana Garnham, general secretary of the AMRC, says she was taken aback at the Charity Commission's failure to spot what appeared to be clear irregularities.

Garnham adds that the case also shows that the commission still fails to understand the need for medical research proposals to be independently refereed, despite the publication of guidelines to this effect in 1994, one year before the Transplant Research Foundation was registered.

The guidelines followed a controversy involving Britain's two largest cancer chari- ties, the Cancer Research Campaign and the Imperial Cancer Research Fund. These charities had funded and publicized the work of a PhD student at the Bristol Cancer Help Centre whose research later turned out to be flawed and which lacked adequate supervision.

The Charity Commission published its guidelines for medical research charities after the so-called Bristol Inquiry (see Nature 369, 428; 1994). But Garnham says that, despite the guidelines, the commission has acknowledged to the AMRC that it lacks expertise in medical research funding matters.

She warns that this could erode confidence in medical charities. "If the Charity Commission can publish guidelines and not enforce them, where does that leave the public who donate money?"

A spokesman for the commission says the foundation's financial situation was "not as healthy as they thought it was". But he adds: "At the time we registered the fund it did meet our criteria." The spokesman, however, was unable to confirm whether the criteria included compliance with the guidelines.

The investigation was prompted by a complaint from Hannah Gould, professor of molecular biology and biophysics at King's College, London, who was concerned at the methods used to assess research applications. Each applicant had been invited by the foundation to become a 'reviewer' for other grant applications and was asked to score these - as well as their own application - on a scale of 1 to 25. Applicants were left free to devise their own criteria for scoring projects.

Gould says she assessed 50 applications. She was also asked to be one of the foundation's trustees. "It was all very silly," she says.

Numerous efforts to contact the foundation's director general Rick Holland this week were unsuccessful. The telephone and e-mail numbers on the foundation's headed notepaper were no longer in service, and Holland's private telephone was not listed in the UK telephone directory. EhsanMasood

\section{Hubble sheds new light on Saturn's poles}

[WASHINGTON] Spectacular details of the auroral curtains of ultraviolet light around Saturn's north and south poles have been observed for the first time by the Space Telescope Imaging Spectrograph on board the Hubble Space Telescope. The

photograph (right), released last week, was taken in October, when Saturn was 1.3 billion $\mathrm{km}$ from Earth.

When used as a camera, the new instrument is more than ten times as

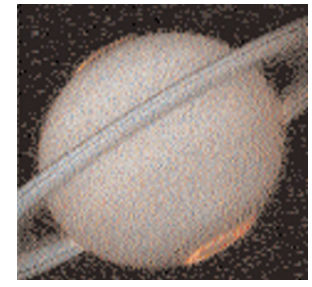

sensitive as previous Hubble instruments in the ultraviolet. Saturn's auroral displays are caused by an energetic wind from the Sun that sweeps over the planet. Unlike Earth, Saturn's aurora is seen only in ultraviolet light invisible from the Earth's surface. 